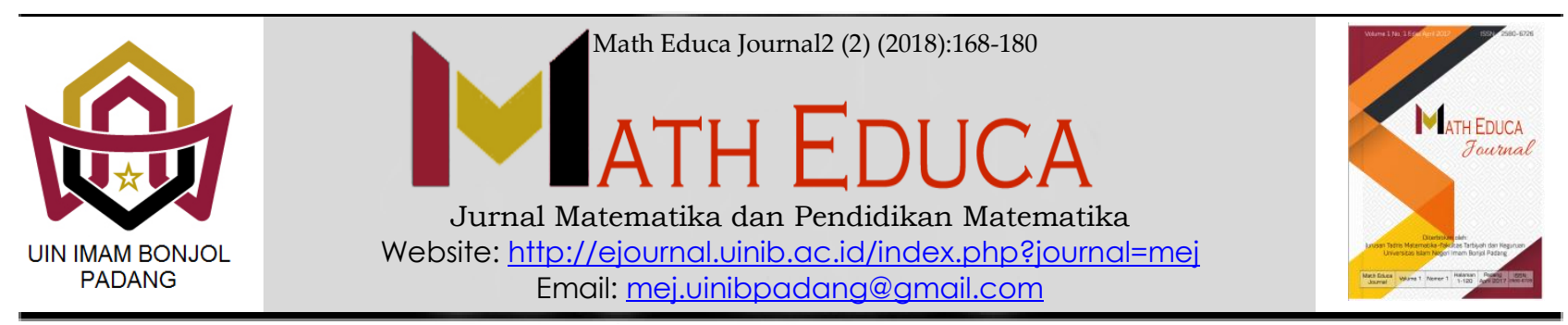

\title{
Eksperimentasi Teknik Quick On The Draw pada Pembelajaran Matematika Peserta Didik Kelas VIII SMPN 1 Ranah Batahan Kabupaten Pasaman Barat
}

\author{
'Yulia, ${ }^{2}$ Asmaiwaty Arief, ${ }^{3}$ Apria Nora \\ Tadris Matematika, Fakultas Tarbiyah dan Kegurvan UIN IB Padang, Indonesia \\ yuliayo99@ymail.com
}

Received: August 2018; Accepted: September 2018; Published: October 2018

\begin{abstract}
Abstrak
Tujuan penelitian ini adalah untuk mengetahui apakah kemampuan pemahaman konsep matematis peserta didik yang diajarkan dengan teknik quick on the draw lebih baik daripada kemampuan pemahaman konsep matematis peserta didik yang menggunakan pembelajaran konvensional pada peserta didik kelas VIII SMPN 1 Ranah Batahan Kabupaten Pasaman Barat. Jenis penelitian ini adalah eksperimen semu dengan rancangan penelitian Randomized Control Group Only Design. Populasi dalam penelitian ini adalah seluruh peserta didik kelas VIII SMPN 1 Ranah Batahan Kabupaten Pasaman Barat terdiri dari 4 kelas. Untuk menentukan kelas eksperimen dan kelas kontrol maka dilakukan secara acak. Kelas yang terpilih sebagai kelas eksperimen adalah kelas VIII.2 dan kelas kontrol adalah kelas VIII.3. Hipotesis penelitian ini adalah kemampuan pemahaman konsep matematis peserta didik yang diajarkan dengan teknik quick on the draw lebih baik daripada kemampuan pemahaman konsep matematis peserta didik yang menggunakan pembelajaran konvensional pada peserta didik kelas VIII SMPN 1 Ranah Batahan Kabupaten Pasaman Barat. Berdasarkan nilai tes akhir diperoleh rata-rata nilai kelas eksperimen 70.89 dan rata-rata nilai kelas kontrol adalah 57.78. Pengujian hipotesis menggunakan uji-t, diperoleh $t_{\text {hitung }}>t_{\text {tabel }}(1.97>1.68)$ dengan taraf kepercayaan $95 \%$, maka hipotesis diterima. Jadi, dapat disimpulkan bahwa kemampuan pemahaman konsep matematis peserta didik yang diajarkan dengan teknik quick on the draw lebih baik daripada kemampuan pemahaman konsep matematis peserta didik yang menggunakan pembelajaran konvensional pada peserta didik kelas VIII SMPN 1 Ranah Batahan Kabupaten Pasaman Barat. Berdasarkan uraian di atas maka peneliti memberikan saran kepada pendidik bidang studi matematika, agar menjadikan teknik Quick on the draw sebagai salah satu alternatif untuk meningkatkan kemampuan pemahaman konsep matematis peserta didik dalam belajar matematika.
\end{abstract}

Kata kunci : Teknik Quick On The Draw, Kemampuan Pemahaman Konsep Matematis

\begin{abstract}
The purpose of this study is to determine the understanding on mathematic concept who were taught by using Quick On The Draw Technique was better than the students who were taught by using conventional technique at Class VIII SMPN 1 Ranah Batahan Kabupaten Pasaman Barat. Quasi experimental that designed randomized control group only design. The population of this research was class VIII students of SMP N 1 Ranah Batahan Kabupaten Pasaman Barat of 4 class. For determine the experimental class and the control class is done by randomly. Classes are chosen as experimental class is a class experiment is VIII.2 class and
\end{abstract}

\footnotetext{
${ }^{*}$ Corresponding author.

Peer review under responsibility UIN Imam Bonjol Padang.

(c) 2018 UIN Imam Bonjol Padang. All rights reserved.

p-ISSN: 2580-6726

e-ISSN: 2598-2133
} 
control class is the class VIII.3. The hypothesis of this study is understanding on mathematic concept who were taught using Quick On The Draw Technique was better that the students who were taught using conventional technique at class VIII of SMPN 1 Ranah Batahan Kabupaten Pasaman Barat. Based on the result of final test students' understanding on mathematic concept in experiment class was higher than the control class. It can be seen from the mean score of experiment class 70.89, control class was 57.78 . Hypothesis testing by using t-test showed that $t$ was higher than $t_{\text {hitung }}>t_{\text {tabel }}(1.97>1.68)$ with degree of freedom $95 \%$ so hypothesis is accepted. In conclusion, students' understanding on mathematic concept who were taught by using Quick On The Draw technique was higher than the students who were taught by using conventional technique at calss VIII of SMPN 1 Ranah Batahan Kabupaten Pasaman Barat. Based on the above description the researcher gives advice to mathematical educator, to make quick on the draw technique as one of alternative to improve understanding of mathematical concepts of learners.

Key Word : Quick on The Draw Technique, Understanding on Mathematic Concept

\section{PENDAHULUAN}

Pendidikan pada hakikatnya tidak dapat dipisahkan dari kehidupan manusia, karena pendidikan mampu menciptakan manusia yang unggul, mandiri, berakhlak mulia dan bertakwa. Selain itu pendidikan sangat penting dalam pembangunan, maka tidak salah jika pemerintah senantiasa selalu berusaha untuk meningkatkan mutu pendidikan mulai dari tingkat rendah sampai ke perguruan tinggi.

Mengingat pentingnya peranan pendidikan menyebabkan pemerintah selalu berusaha meningkatkan mutu pendidikan disetiap jenjang pendidikan, khususnya pendidikan matematika agar menjadi lebih baik. Diantara usaha yang bisa dilakukan adalah peningkatan kualitas pendidik atau yang lebih dikenal dengan sertifikasi pendidik, perbaikan kurikulum, melengkapi sarana danp rasarana dan lain-lain.

Pendidik sebagai komponen utama dalam pembelajaran harus berusaha semaksimal mungkin memberikan suatu solusi agar hasil belajar peserta didik memuaskan, selain itu pendidik juga harus memperhatikan bagaimana keinginan dari peserta didik untuk menerima pelajaran, karena hasil yang diperoleh akan sebanding dengan usaha yang dilakukan. Sebagaimana firman Allah SWT surat An-Najm ayat 39-41:

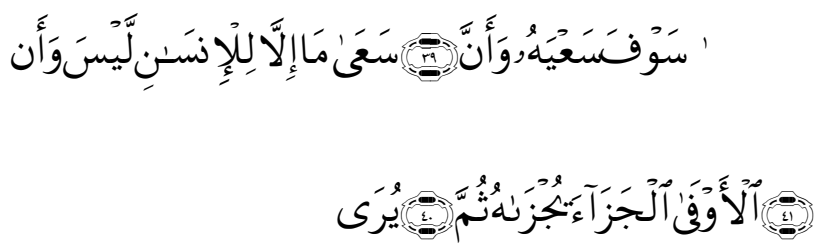

Artinya :"Dan bahwasanya seorang manusia tiada memperoleh selain apa yang telah diusahakannya, dan bahwasanya usaha itu kelak akan diperlihat (kepadanya), kemudian akan diberi Balasan kepadanya dengan Balasan yang paling sempurna”. (QS.An-Najm, 53: 39 - 41).

Ayat di atas dapat dijadikan pedoman seorang pendidik dalam memberikan suatu motivasi untuk berusaha menemukan teknik dalam mengajar agar hasil belajar peserta didik memuaskan dan meningkat. Matematika merupakan salah satu mata pelajaran wajib yang diajarkan pada setiap jenjang pendidikan di sekolah diharapkan dapat memberikan 
sumbangan dalam rangka mengembangkan kemampuan berpikir secara kritis, sistematis, logis dan kreatif dalam mencari solusi pemecahan sebuah masalah.

Berdasarkan Permendikbud No.21 tahun 2016, salah satu kemampuan matematika yang perlu dicapai adalah kemampuan pemahaman konsep matematis. Kemampuan pemahaman konsep matematis peserta didik yang baik akan membantu peserta didik dalam menyelesaikan permasalahan yang diberikan oleh pendidik.

Rendahnya kemampuan pemahaman konsep matematis peserta didik juga berdampak pada hasil belajar matematika yang dicapai oleh peserta didik. Persentase nilai Ujian Semester II matematika peserta didik kelas VII di SMPN 1 Ranah Batahan Kabupaten Pasaman Barat masih banyak di bawah Kriteria Ketuntasan Minimal (KKM) yang ditetapkan yaitu 75. Jika hal ini dibiarkan maka akan berdampak pada rendahnya nilai matematika peserta didik, untuk mengatasi masalah tersebut, pendidik sebagai salah satu komponen utama dalam pendidikan diharapkan mampu melakukan variasi-variasi dalam pembelajaran.

Berdasarkan hasil observasi yang dilakukan oleh peneliti di kelas VII SMPN 1 Ranah Batahan Kabupaten Pasaman Barat pada tanggal 17 April 2017 bahwa masih banyak peserta didik yang kurang terlibat aktif dalam proses pembelajaran, hal ini terlihat dari peserta didik kurang berani menjawab pertanyaan yang diajukan pendidik. Sebagian peserta didik malas bertanya dan menanggapi pelajaran. Sebagian peserta didik hanya berpedoman kepada contoh yang diberikan oleh pendidik, sehingga jika soal yang diberikan pendidik berubah sedikit dari contoh soal, peserta didik mengalami kesulitan dalam menyelesaikan soal. Sebagian peserta didik hanya menduplikasi jawaban peserta didik yang memiliki kemampuan lebih tinggi dari peserta didik lain.

Selain itu, proses pembelajaran masih cenderung terpusat pada pendidik. Peserta didik membutuhkan waktu yang lama untuk menyelesaikan soal latihan. Peserta didik tidak dibiasakan berdiskusi dan mengkonstruksi pengetahuan yang diterimanya sehingga peserta didik kurang memahami konsep dengan baik. Peserta didik lebih cenderung menghafal rumus-rumus daripada memahami konsep matematika yang diberikan, akibatnya peserta didik kurang paham terhadap materi yang diajarkan. Sebagian peserta didik kebingungan dalam menyelesaikan soal yang diberikan pendidik, sebab kurangnya kemampuan peserta didik dalam memahami konsep materi pelajaran yang diberikan.

Berdasarkan permasalahan di SMPN 1 Ranah Batahan Kabupaten Pasaman Barat, maka pendidik matematika harus menciptakan suatu teknik pembelajaran yang menarik dan disenangi oleh peserta didik sehingga matematika menjadi pelajaran yang disukai. Salah satu teknik pembelajaran yang dapat 
mengatasi permasalahan tersebut adalah teknik quick on the draw.

Quick on the draw merupakan kompetisi antar kelompok dimana yang menjadi pemenang dalam kompetisi ini adalah kelompok yang mampu menjawab satu set pertanyaan dengan cepat. Semua kelompok akan bersaing karena masing-masing kelompok diberikan tenggang waktu untuk menyelesaikan kartu soal. Seperti yang diungkapkan oleh Paul Ginnis (2008: 163) "Quick on the draw adalah sebuah aktivitas riset dengan insentif bawaan untuk kerja tim dan kecepatan".

Melalui eksperimentasi teknik quick on the draw diharapkan peserta didik akan terlibat langsung dalam proses pembelajaran. Selain itu dapat meningkatkan kemampuan pemahaman konsep matematis peserta didik yang pada akhirnya peserta didik dapat menyelesaikan masalah matematika dengan baik.

Berdasarkan uraian di atas, maka peneliti tertarik untuk melakukan penelitian di SMPN 1 Ranah Batahan Kabupaten Pasaman Barat dengan judul “Eksperimentasi Teknik Quick On The Draw Pada Pembelajaran Matematika Peserta Didik Kelas VIII SMPN 1 Ranah Batahan Kabupaten Pasaman Barat“.

Berdasarkan latar belakang dan identifikasi masalah maka permasalahan dalam penelitian ini dibatasi pada kemampuan pemahaman konsep matematis peserta didik yang diajarkan dengan teknik quick on the draw kelas VIII SMPN 1 Ranah Batahan Kabupaten Pasaman Barat.

Penelitian ini bertujuan untuk mengetahui apakah kemampuan pemahaman konsep matematis peserta didik yang diajarkan dengan teknik quick on the draw lebih baik daripada kemampuan pemahaman konsep matematis peserta didik yang menggunakan pembelajaran konvensional pada peserta didik kelas VIII SMPN 1 Ranah Batahan Kabupaten Pasaman Barat.

Keberhasilan belajar matematika peserta didik dengan menggunakan teknik quick on the draw dilihat dari penelitian yang dilakukan oleh Anisa Juwita (Skripsi) yang berjudul“"Penerapan Teknik Pembelajaran Quick On The Draw Untuk meningkatkan Kemampuan Penalaran Matematis Siswa Kelas XI MIA SMAN 4 Padang". Hasil yang diperolehnya adalah kemampuan penalaran matematis siswa yang menerapkan tekhnik pembelajaran quick on the draw lebih baik daripada kemampuan penalaran matematis siswa yang menerapkan pembelajaran konvensional. Perbedaan penelitian adalah peneliti melakukan eksperimentasi teknik quick on the draw pada pembelajaran matematika peserta didik kelas VIII SMPN 1 Ranah Batahan Kabupaten Pasaman Barat yaitu pada kemampuan pemahaman konsep matematis peserta didik. 


\section{METODE PENELITIAN}

\section{Jenis Penelitian}

Jenis penelitian ini menggunakan penelitian eksperimen semu, di mana dalam penelitian ini terdiri dari kelas eksperimen dan kelas kontrol yang diberikan perlakuan tidak sama. Untuk kelas eksperimen dilakukan eksperimentasi teknik quick on the draw sedangkan pada kelas kontrol dilakukan pembelajaran konvensional. Penelitian ini menggunakan rancangan penelitiannya adalah Randomized Control Group Only Design.

\section{Populasi dan Sampel}

Populasi dalam penelitian ini adalah peserta didik kelas VIII SMPN 1 Ranah Batahan Kabupaten Pasaman Barat. Pengambilan sampel dilakukan setelah dilakukan uji normalitas, uji homogenitas variansi dan uji kesamaan rata-rata. Pada saat uji normalitas didapatkan hasil populasi berdistribusi normal. Pada uji homogenitas variansi didapatkan tingkat signifikan berada diatas 0,05, sehingga dapat disimpulkan bahwa seluruh populasi memiliki variansi yang sama atau homogen.Teknik pengambilan sampel, dipilih dua kelas secara acak. Pengambilan sampel pertama adalah kelas eksperimen, sedangkan pengambilan kedua adalah kelas kontrol. Untuk kelas eksperimen terpilih kelas VIII.2 sedangkan kelas kontrol terpilih kelas VIII.3. Variabel bebas dalam penelitian ini adalah ekperimentasi teknik quick on the draw pada pembelajaran matematika peserta didik kelas VIII SMPN 1
Ranah Batahan Kabupaten Pasaman Barat.Variabel terikat dalam penelitian ini adalah kemampuan pemahaman konsep matematis peserta didik setelah diajarkan dengan teknik quick on the draw.

\section{Prosedur}

Prosedur dalam penelitian ini terdiri dari tiga tahapan, yaitu tahap persiapan, tahap pelaksanaan, dan tahap penyelesaian. Pada tahap persiapan yang dilakukan adalah mempersiapkan segala persiapan penelitian, melakukan observasi, meminta data nilai mentah ujian semester II matematika peserta didik, mempersiapkan surat izin penelitian, menentukan jadwal penelitian, mempersiapkan Rencana Pelaksanaan Pembelajaran (RPP) sebagai pedoman dalam proses pengajaran matematika. Kemudian RPP diberikan kepada dosen dan pendidik mata pelajaran matematika untuk divalidasi, mempersiapkan alat-alat yang dibutuhkan, mempersiapkan kisi-kisi soal tes uji coba hasil belajar, mempersiapkan dan menyusun soal-soal tes akhir, melakukan uji coba tes dan melakukan tes akhir.

Pada tahap pelaksanaan, meliputi pelaksanaan pembelajaran di kelas eksperimen dengan menggunakan teknik quick on the draw, sedangkan pada kelas kontrol diajar dengan menggunakan pembelajaran konvensional. Pada tahap akhir dilakukan tes akhir untuk mengetahui kemampuan pemahaman konsep matematis peserta didik sehingga diperoleh hasil belajar peserta didik. 
Langkah-langkah pemberian tes tersebut adalah melaksanakan uji coba tes, tes akhir, analisis tes akhir, menarik kesimpulan dan menulis hasil penelitian.

\section{Data, Intrumen, dan Teknik Pengumpulan Data}

Data di dalam penelitian ini adalah data kemampuan konsep matematis peserta didik. Instrumen yang digunakan dalam penelitian ini berupa tes berbentuk uraian (essay) sebanyak lima butir soal. Sebelum digunakan instrumen tersebut divalidasi oleh validator untuk menguji validitas dan ketepatan penggunaannya.

Teknik pengumpulan data yang digunakan untuk mengetahui pemahaman konsep matematis peserta didik setelah dilakukan tes, lembar jawaban akan dikumpulkan kemudian dilakukan penskoran sesuai dengan rubrik indikator pemahaman konsep matematis.

\section{Teknik Analisis Data}

Teknik analisis data dilakukan untuk menguji hipotesis yang diajukan dalam penelitian ini. Kemampuan pemahaman konsep matematis peserta didik dinilai dari tes akhir yang mengandung indikator pemahaman konsep dengan eksperimentasi teknik quick on the draw.

Berdasarkan indikator kemampuan pemahaman konsep matematis yang telah dijelaskan, maka penulis menggunakan rubrik analitik (Iryanti, 2004: 13) untuk menghitung skor kemampuan pemahaman konsep matematis. "Rubrik analitik adalah pedoman untuk menilai berdasarkan beberapa kriteria yang ditentukan. Dengan menggunakan rubrik ini dapat menganalisa kelemahan dan kelebihan peserta didik yang terletak pada kriteria yang ditentukan".

Berdasarkan rubrik yang sudah dibuat dapat dinilai tes akhir yang dilakukan peserta didik. Skor yang diperoleh peserta didik masih harus dirubah kedalam skala angka yang ditetapkan yaitu ke skala 0-100.

Nilai kemampuan pemahaman konsep peserta didik

$$
=\frac{\text { skor yang diperoleh peserta didik }}{\text { skor total }} \times 100
$$

Teknik analisis data yang penulis gunakan dalam penelitian ini adalah dengan menggunakan uji-t. Adapun syarat untuk dilakukan uji-t terhadap pemahaman konsep matematis, terlebih dalulu dilakukan uji normalitas dan uji homogenitas. Untuk mengetahui persyaratan analisis terlebih dahulu dicari rata-rata, simpangan baku dan variansi kedua sampel, kemudian dilakukan uji normalitas dan uji homogenitas dari data kedua kelas sampel. Untuk melakukan uji normalitas dan uji homogenitas, maka penulis melakukan langkah-langkah sebagai berikut:

\section{Uji Normalitas}

Uji normalitas hasil belajar peserta didik ini sama caranya dengan uji normalitas ketika peneliti menentukan sampel, yaitu dilakukan menggunakan SPSS dan secara manual. Sedangkan pengujian secara manual dilakukan 
dengan uji Liliefors. Pedoman pengambilan keputusan :

a. Jika signifikansi atau nilai probabilitas $>0,05$ maka distribusi sampel data normal.

b. Jika signifikansi atau nilai probabilitas $<0,05$ maka distribusi sampel data tidak normal.

Untuk melihat apakah sampel berdistribusi normal atau tidak dapat juga dilakukan dengan menggunakan grafik normal Q-Q plot yaitu data berdistribusi normal jika pencacaran plot data berada sekitar garis melintang. Cara lain yang dilakukan adalah dengan uji Kolmogorov-Smirnov yaitu data berdistribusi normal jika P-value yang diperoleh lebih besar dari 0,05. Selain itu, uji normalitas juga dilakukan dengan menggunakan uji liliefors.

\section{Uji Homogenitas Variansi}

Pengujian ini bertujuan untuk melihat apakah kedua kelompok data hasil belajar peserta didik mempunyai variansi yang homogen atau tidak. Hipotesis yang diajukan adalah :

$$
\begin{aligned}
& H_{0}: \sigma_{1}^{2}=\sigma_{2}^{2} \\
& H_{1}: \sigma_{1}^{2} \neq \sigma_{2}^{2}
\end{aligned}
$$

Dalam hal ini uji homogenitas variansi dilakukan dengan menggunakan uji $F$. Langkah-langkah uji homogenitas variansi menurut Sudjana (2005: 250) yaitu :

a. Menghitung variansi masing-masing kelompok data b. Menghitung harga F dengan menggunakan rumus :

$$
F=\frac{S_{1}^{2}}{S_{2}^{2}}
$$

Keterangan :

$F=$ Variansi kelompok data

$S_{1}=$ Variansi data hasil belajar kelas eksperimen

$S_{1}=$ Variansi data hasil belajar kelas kontrol

Kriteria pengujian :

1) Jika $F_{\text {hitung }}<F_{\text {tabel }}$ maka $H_{0}$ diterima ini berarti kedua kelompok data mempunyai variansi yang homogen.

2) Jika $F_{\text {hitung }}>F_{\text {tabel }}$ maka $H_{1}$ diterima ini berarti kedua kelompok data mempunyai variansi yang tidak homogen.

\section{Uji Hipotesis}

Uji hipotesis ini bertujuan untuk membuktikan apakah hipotesis yang ditetapkan memang benar atau tidak, maksudnya adalah apakah kemampuan pemahaman konsep matematis peserta didik yang diajarkan dengan teknik quick on the draw lebih baik daripada kemampuan pemahaman konsep matematis peserta didik yang menggunakan pembelajaran konvensional pada peserta didik kelas VIII SMPN 1 Ranah Batahan Kabupaten Pasaman Barat. Berdasarkan hipotesis yang dikemukakan, maka dilakukan uji satu pihak dengan rumusan hipotesis :

$$
\begin{aligned}
& H_{0}: \mu_{1}=\mu_{2} \\
& H_{1}: \mu_{1}>\mu_{2}
\end{aligned}
$$

Keterangan : 
$\mu_{1}:$ Rata-rata kemampuan

pemahaman konsep matematis peserta didik kelas eksperimen

$\mu_{2}:$ Rata-rata kemampuan pemahaman konsep matematis peserta didik kelas kontrol

Jika data berdistribusi normal dan kedua kelompok data memiliki variansi yang homogen, maka dalam pengujian hipotesis statistik digunakan rumus (Sudjana, 2005: 239) yaitu :

$$
\begin{gathered}
t=\frac{\overline{x_{1}}-\overline{x_{2}}}{s \sqrt{\frac{1}{n_{1}}+\frac{1}{n_{2}}}} \\
S^{2}=\frac{\left(n_{1}-1\right) S_{1}^{2}+\left(n_{2}-1\right) S_{2}^{2}}{n_{1}+n_{2}-2}
\end{gathered}
$$

Keterangan :

$\overline{x_{1}}=$ Nilai rata-rata kelas eksperimen

$\overline{x_{2}}=$ Nilai rata-rata kelas kontrol

$s$ = Simpangan baku kedua kelompok

data

$n_{1}=$ Jumlah peserta didik kelas

eksperimen

$n_{2}=$ Jumlah peserta didik kelas kontrol

$S_{1}^{2}=$ Simpangan baku kelas eksperimen

$S_{2}^{2}=$ Simpangan baku kelas kontrol

Kriteria pengujian adalah terima $H_{0}$ jika $t<t_{(1-\alpha)}$ pada taraf kepercayaan 95\%, jika jika $t>t_{(1-\alpha)}$ pada taraf kepercayaan 95\% maka $H_{0}$ ditolak. Dimana $t_{(1-\alpha)}$ didapat dari daftar distribusi $t$ dengan derajat kebebasan $(d f)=n_{1}+n_{2}-2$ dan peluang $(1-\alpha)$. Dari perhitungan uji-t diperoleh $t_{\text {hitung }}=1.97$, sedangkan $t_{\text {tabel }}=1.68$ dengan taraf nyata $\alpha=0.05$ adalah. Karena $t_{\text {hitung }}>$ $t_{\text {tabel }}(1.97>1.68)$. Hal ini berarti bahwa $H_{0}$ ditolak dan $H_{1}$ diterima, maka dapat disimpulkan bahwa hipotesis dalam penelitian ini diterima.

\section{HASIL PENELITIAN DAN PEMBAHASAN}

Data penelitian yang dideskripsikan yaitu data kemampuan pemahaman konsep peserta didik dengan Eksperimentasi Teknik Quick On The Draw di Kelas VIII SMPN 1 Ranah Batahan Kabupaten Pasaman Barat. Berdasarkan nilai tes ini selanjutnya dikelompokkan berdasarkan indikator kemampuan pemahaman konsep dan dicari nilai rata-rata setiap indikator untuk masingmasing kelas eksperimen dan kelas kontrol.

Tabel 4.1

Pengelompokkan Nilai Tes Akhir Kemampuan Pemahaman Konsep

\begin{tabular}{|c|c|c|c|c|c|}
\hline \multirow[t]{2}{*}{$\begin{array}{l}\mathrm{N} \\
\mathrm{O}\end{array}$} & \multirow{2}{*}{$\begin{array}{l}\text { Indikator } \\
\text { Kemampuan } \\
\text { Pemahaman } \\
\text { Konsep }\end{array}$} & \multirow[t]{2}{*}{ Soal } & \multirow[t]{2}{*}{$\begin{array}{l}\text { Sko } \\
\text { r }\end{array}$} & $\begin{array}{l}\text { Eksperime } \\
\mathrm{n}\end{array}$ & $\begin{array}{l}\text { Kontro } \\
\mathrm{I}\end{array}$ \\
\hline & & & & $\bar{x}$ & $\bar{x}$ \\
\hline 1. & $\begin{array}{l}\text { Menyatakan } \\
\text { ulang sebuah } \\
\text { konsep }\end{array}$ & $1 a, 1 b$ & 6 & 6.10 & 5.65 \\
\hline 2. & $\begin{array}{l}\text { Mengklasifikasika } \\
\text { n objek menurut } \\
\text { sifat-sifat } \\
\text { tertentu sesuai } \\
\text { dengan } \\
\text { konsepnya } \\
\end{array}$ & $\begin{array}{c}2 \mathrm{a}, 2 \\
\mathrm{~b}\end{array}$ & 12 & 8.24 & 7.85 \\
\hline 3. & $\begin{array}{l}\text { Mengaplikasikan } \\
\text { objek atau } \\
\text { algoritma } \\
\text { pemecahan } \\
\text { masalah } \\
\end{array}$ & $\begin{array}{c}3,4 \\
\text { dan } \\
5\end{array}$ & 27 & 17.43 & 12.55 \\
\hline
\end{tabular}
Kelas Eksperimen dan Kelas Kontrol

Dilihat dari tabel di atas, pada indikator kemampuan pemahaman konsep yang pertama untuk soal nomor 1a dan 1b, peserta didik di kelas eksperimen mendapatkan nilai rata-rata 6.10. Sedangkan untuk peserta didik kelas kontrol mendapatkan nilai rata-rata 5.65. Pada 
indikator kedua untuk soal nomor $2 a$ dan $2 b$, peserta didik di kelas eksperimen mendapatkan nilai rata-rata 8.24. Sedangkan untuk peserta didik kelas kontrol mendapatkan nilai rata-rata 7.85. Pada indikator ketiga untuk soal nomor 3, 4 dan 5, peserta didik kelas eksperimen mendapatkan nilai rata-rata 17.43 . Sedangkan untuk peserta didik kelas kontrol mendapatkan nilai rata-rata 12.55

Selain itu nilai rata-rata setiap indikator kemampuan pemahaman konsep pada kelas sampel dapat juga dilihat pada diagram berikut

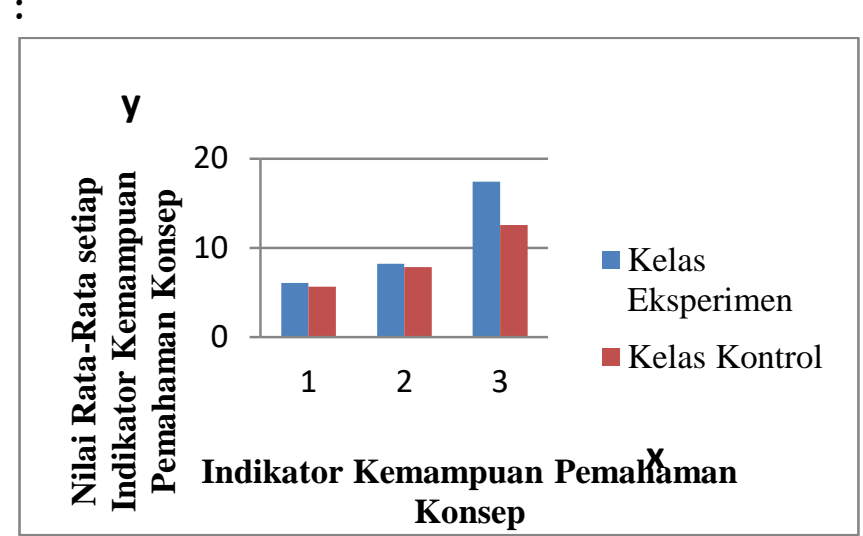

Gambar 4.1: Nilai Rata-Rata setiap Indikator Kemampuan Pemahaman Konsep pada Kelas Sampel.

Keterangan:

$1=$ Menyatakan ulang sebuah konsep

2=Mengklasifikasikan objek menurut sifat-sifat tertentu sesuai dengan konsepnya

3=Mengaplikasikan objek atau algoritma pemecahan masalah.

Dari deskripsi data di atas dapat dilihat bahwa nilai rata-rata hasil tes akhir kemampuan pemahaman konsep matematis peserta didik kelas eksperimen pada setiap indikator lebih tinggi dari nilai rata-rata hasil tes akhir kemampuan pemahaman konsep matematis peserta didik kelas kontrol.

Selanjutnya dicari skor rata-rata $(\bar{x})$, standar deviasi $(s)$, skor tertinggi $\left(x_{\max }\right)$ dan skor terendah $\left(x_{\min }\right)$. Kesimpulan hasil perhitungan tersebut dapat dilihat pada tabel sebagai berikut:

Tabel 4.2

Deskripsi Data Kemampuan Pemahaman Konsep Matematis Kelas Eksperimen dan Kelas Kontrol

\begin{tabular}{|c|c|c|}
\hline Besaran & Eksperimen & Kontrol \\
\hline$N$ & 21 & 20 \\
\hline$x_{\min }$ & 33.33 & 30 \\
\hline$x_{\max }$ & 100 & 86.67 \\
\hline$\sum x$ & 1488.60 & 1155.57 \\
\hline $\bar{x}$ & 70.89 & 57.78 \\
\hline $\begin{array}{c}\text { Standar Deviasi }(s) \\
\text { Variances }\left(S^{2}\right)\end{array}$ & 19.62 & 22.97 \\
\hline $\begin{array}{c}\text { Jumlah Ketuntasan } \\
\text { Individu }\end{array}$ & 385.05 & 527.63 \\
\hline $\begin{array}{c}\text { Persentase } \\
\text { Ketuntasan Klasikal }\end{array}$ & $52.38 \%$ & 6 \\
\hline
\end{tabular}

Dari tabel di atas, dapat dilihat bahwa nilai rata-rata tes akhir peserta didik kelas eksperimen yang terdiri dari 21 orang peserta didik yaitu 70.89 lebih tinggi dari nilai rata-rata hasil belajar kemampuan pemahaman konsep matematis peserta didik kelas kontrol yang terdiri dari 20 orang peserta didik yaitu 57.78 . Variansi kelas eksperimen yaitu 385.05 dan variansi kelas kontrol yaitu 527.63. Standar deviasi kelas eksperimen yaitu 19.62 dan standar deviasi kelas kontrol yaitu 22.97. Nilai maksimum hasil tes akhir kelas eksperimen yaitu 100 lebih tinggi dari nilai maksimum hasil tes akhir kelas kontrol yaitu 86.67 dan nilai minimum kelas eksperimen yaitu 33.33 lebih tinggi dari kelas kontrol yaitu 30.

Berdasarkan KKM yang telah ditetapkan di SMPN 1 Ranah Batahan Kabupaten Pasaman Barat yaitu 75 pada pelajaran matematika dari tes akhir kemampuan pemahaman konsep matematis peserta didik pada kelas eksperimen diketahui bahwa 11 orang peserta didik 
mendapat nilai $\geq K K M$, sedangkan pada kelas kontrol hanya 6 orang peserta didik, sehingga persentase ketuntasan masing-masing kelas eksperimen dan kelas kontrol berturut-turut adalah $52.38 \%$ dan $30 \%$. Artinya kemampuan pemahaman konsep matematis kelas eksperimen lebih baik daripada kemampuan pemahaman konsep matematis kelas kontrol.

Untuk memperoleh kesimpulan tentang data hasil pemahaman konsep matematis peserta didik dilakukan analisis secara statistik. Sebelum uji statistik untuk hipotesis, terlebih dahulu dilakukan uji normalitas dan homogenitas.

1. Uji Normalitas

a. Uji normalitas data hasil belajar kemampuan pemahaman konsep matematis kelas sampel bertujuan untuk mengetahui apakah data berdistribusi normal atau tidak. Uji yang digunakan adalah uji liliefors.

Berdasarkan pengujian untuk kelas eksperimen diperoleh: $L_{0}=0.1799$ dan $L_{\text {tabel }}=0.1933$, karena $L_{0}<L_{\text {tabel }}(0.1799<$ 0.1933) maka $H_{0}$ diterima, sehingga dapat disimpulkan bahwa kelas eksperimen berdistribusi normal pada taraf kepercayaan $95 \%$.

b. Uji normalitas kelas kontrol

Berdasarkan pengujian untuk kelas kontrol diperoleh: $L_{0}=0.1294$ dan $L_{\text {tabel }}=$ 0.1900 , karena $L_{0}<L_{\text {tabel }}(0.1294<0.1900)$ maka $H_{0}$ diterima, sehingga dapat disimpulkan bahwa kelas kontrol berdistribusi normal pada taraf kepercayaan 95\%.

Selain itu untuk menentukan data berdistribusi normal atau tidak, penulis juga melakukan pengujian normalitas dengan software SPSS. Dengan menggunakan natuan software SPSS dapat dilihat hasil uji normalitas kedua kelas sampel sebagai berikut :

Tabel 4.4

Tests of Normality

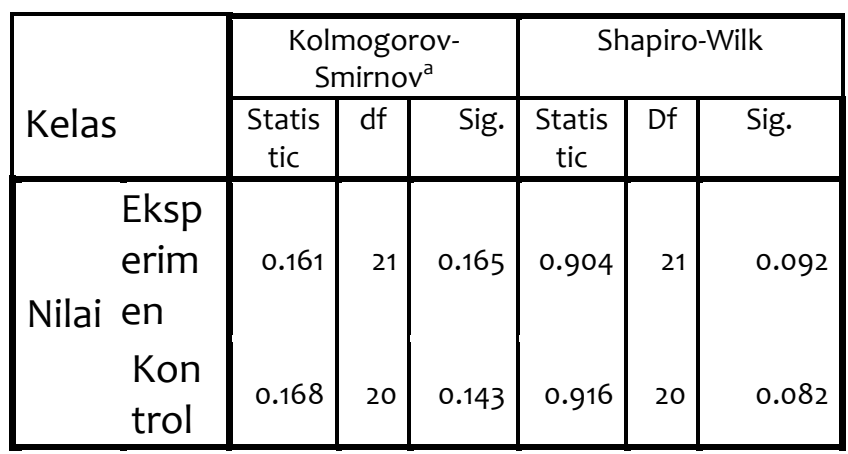

a. Lilliefors Significance Correction

Berdasarkan uji Kolmogorov-Smirnov baik kelas eksperimen maupun kelas kontrol didapat tingkat signifikan lebih besar dari 0.05 yaitu 0.161 dan 0.168 .

1. Uji Homogenitas

Uji homogenitas variansi ini bertujuan untuk melihat kedua kelompok data mempunyai variansi yang homogen atau tidak.Secara manual uji homogenitas variansi dilakukan dengan uji F.

$$
F=\frac{S_{1}^{2}}{S_{2}^{2}}
$$

Keterangan:

$F=$ Sebaran $F$

$S_{1}^{2}=$ Variansi kelas eksperimen

$S_{2}^{2}=$ Variansi kelas kontrol

Terima $H_{0}$ jika $F_{\text {hitung }}<F_{\text {tabel }}$ 
Berdasarkan rumus di atas, diperoleh nilai $F_{\text {hitung }}$ dari kedua kelas sampel yaitu: $F=$ 0.730 dan berdasarkan tabel distribusi $F$ diperoleh nilai $F_{\text {tabel }}$ untuk taraf nyata $\alpha=0,05$ dan derajat kebebasan $(d f)=\left(n_{1}-1, n_{2}-\right.$ 1) $=(20,19)$ adalah 2.16. Maka diperoleh $F_{\text {hitung }}<F_{\left(a ; v_{1}, v_{2}\right)}=(0.730<2.16)$ sehingga dapat disimpulkan bahwa kedua kelas sampel memiliki variansi yang homogen.

\section{Uji Hipotesis}

Setelah dilakukan uji normalitas dan uji homogenitas diketahui bahwa skor tes hasil belajar kemampuan pemahaman konsep matematis peserta didik pada kedua kelas sampel berdistribusi normal dan memiliki variansi yang homogen, selanjutnya dilakukan uji hipotesis.

Pada uji hipotesis, uji yang digunakan adalah uji hipotesis satu arah. Rumusan hipotesisnya sebagai berikut:

$$
\begin{aligned}
& H_{0}: \mu_{1}=\mu_{2} \\
& H_{0}: \mu_{1}>\mu_{2}
\end{aligned}
$$

Kriteria $H_{0}$ diterima jika $t_{\text {hitung }}<t_{\text {tabel }}$ pada daftar distribusi- $t$ dengan derajat kebebasan $d f=n_{1}+n_{2}-2$ dan $\alpha=0.05 H_{0}$ ditolak jikat $t_{\text {hitung }}>t_{\text {tabel }}$ pada distribusi- $t$ dengan derajat kebebasan $d f=n_{1}+n_{2}-2$ dan $\alpha=0.05$.

Dari data akhir hasil belajar kemampuan pemahaman konsep matematis peserta didik dan pengolahan uji-t yang dilakukan maka diperoleh $t_{\text {hitung }}=1.97$ dan $t_{\text {tabel }}=1.68$ dengan taraf kepercayaan 95\%. Batas daerah terima $H_{0}$ adalah $t_{\text {hitung }}<t_{\text {tabel }}$ sedangkan $t_{\text {hitung }}$ yang diperoleh adalah 1.97. Ini berarti $t_{\text {hitung }}$ berada di luar daerah penerimaan $H_{0}$. Karena $t_{\text {hitung }}>t_{\text {tabel }}=1.97>1.68$ maka $H_{0}$ ditolak dan $H_{1}$ diterima.

Dengan demikian dapat disimpulkan bahwa kemampuan pemahaman konsep matematis peserta didik yang diajarkan dengan teknik quick on the draw lebih baik daripada kemampuan pemahaman konsep matematis peserta didik yang diajar dengan menggunakan pembelajaran konvensional pada peserta didik kelas VIII SMPN 1 Ranah Batahan Kabupaten Pasaman Barat.

\section{Pembahasan}

Pada kelas eksperimen kegiatan pembelajaran yang diajarkan adalah Teknik quick on the draw. Quick on the draw merupakan kompetisi antar kelompok dimana yang menjadi pemenang dalam kompetisi ini adalah kelompok yang mampu menjawab satu set pertanyaan dengan cepat. Semua kelompok akan bersaing karena masing-masing kelompok diberikan tenggang waktu untuk menyelesaikan kartu soal. Seperti yang diungkapkan oleh Paul Ginnis (2008: 163) "Quick on the draw adalah sebuah aktivitas riset dengan insentif bawaan untuk kerja tim dan kecepatan".

Teknik quick on the draw adalah suatu teknik pembelajaran yang menuntut aktivitas dan kerja sama peserta didik dalam mencari, menyelesaikan dan melaporkan informasi dari berbagai sumber dalam sebuah suasana 
permainan yang mengarah pada pacuan kelompok melalui aktivitas kerja tim dan kecepatannya. Dengan suasana permainan dalam pembelajaran maka akan menarik dan menimbulkan efek kreatifitas dalam belajar peserta didik.

Berdasarkan langkah-langkah pembelajaran yang telah dikemukakan agar pembelajaran berjalan dengan lancar dan sesuai dengan keadaan, tempat dan waktu yang telah ditetapkan, maka peneliti memodifikasinya.Berdasarkan hal di atas dapat disimpulkan bahwa kemampuan pemahaman matematis peserta didik yang diajar dengan menggunakan teknik quick on the draw lebih baik daripada kemampuan pemahaman konsep matematis peserta didik menggunakan pembelajaran konvensional atau dalam hal ini pembelajaran kurikulum 2013.

\section{Kesimpulan}

Setelah dilakukan proses pembelajaran di kelas sampel maka dilakukan tes akhir penelitian untuk melihat efek dari eksperimentasi teknik quick on the draw. Dari hasil penelitian menunjukkan bahwa rata-rata hasil tes akhir kemampuan pemahaman konsep matematis peserta didik kelas eksperimen adalah 70.89 dan kelas kontrol adalah 57.78. Pengolahan data hasil tes akhir dilakukan melalui uji hipotesis yang menggunakan uji-t. Setelah dilakukan perhitungan sehingga diperoleh $t_{\text {hitung }}=1.97$ dan $t_{\text {tabel }}=1.68$ dengan taraf kepercayaan 95\%. Ini berarti $t_{\text {hitung }}>t_{\text {tabel }}(1.97>1.68)$. Hal ini menunjukkan bahwa hipotesis yang diajukan diterima. Sehingga dapat disimpulkan bahwa kemampuan pemahaman konsep matematis peserta didik yang diajarkan dengan teknik Quick On The Draw lebih baik daripada kemampuan pemahaman konsep matematis peserta didik yang menggunakan pembelajaran konvensional.

\section{Saran}

Berdasarkan kesimpulan yang diperoleh dari penelitian ini maka penulis memberikan saran-saran sebagai berikut:

1. Agar pendidik matematika umumnya, khususnya pendidik matematika di SMPN 1 Ranah Batahan Kabupaten Pasaman Barat menggunakan teknik quick on the draw sebagai salah satu alternatif untuk meningkatkan kemampuan pemahaman konsep matematis peserta didik pada pokok bahasan operasi aljabar.

2. Kepada pembaca diharapkan agar hasil penelitian ini dijadikan sebagai salah satu wadah untuk memperkaya wawasan yang telah dimiliki.

3. Diharapkan kepada calon pendidik atau mahasiswa kependidikan untuk mengembangkan penelitian lanjutan.

4. Bagi peneliti berikutnya diharapkan mampu untuk menggunakan dan membagi waktu seefisien mungkin. 


\section{REFERENSI}

Abdusysyakir. 2007. Ketika Kyai Mengajar Matematika. Malang : UIN- Malang.

Ali Ash-shabuni, Syaikh Muhammad. 2011. Shafwatut Tafasir: Tafsir-Tafsir Pilihan. Jakarta: Pustaka Al-Kautsar.

Arikunto, Suharsimi. 2006. Prosedur Penelitian. Jakarta: PT Rineka Cipta.

Dimyati. 1994. Belajar dan Pembelajaran. Jakarta : PT Rineka Cipta.

Ginnis, Paul. 2008. Trik dan Taktik Mengajar; Strategi Meningkatkan Pencapaian Pengajaran di Kelas. Jakarta: Indeks.

Iryanti, Puji. (2004). Penilaian Untuk kerja. Yogyakarta: depdiknas.

Muliyardi. 2002. Strategi Pembelajaran Matematika. Padang: FMIPA UNP.

Mulyasa. 2013. Pengembangan dan Implementasi K urikulum 2013. Bandung: PT Remaja Rosdakarya.

Nasution, S. 2000. Berbagai Pendekatan dalam Proses Belajar Mengajar. Jakarta: Bumi Aksara.

Prawironegoro. 1985. Evaluasi Belajar Khusus Analisa Soal Untuk Bidang Studi Matematika. Jakart : CV Fortuna.

Rusman. 2015. Pembelajaran Tematik Terpadu. Jakarta: PT Raja Grafindo Persada.
Shadiq, Fadjar. 2009. Kemahiran Matematika.Yogyakarta: Depdiknas.

Slameto. 2003. Belajar dan Faktor-Faktor Yang Mempengaruhinya. Jakarta: PT Rineka Cipta.

Sudjana, Nana. 2005. Penelitian hasil Proses Belajar Mengajar. Bandung: Sinar Baru Algesindo.

Sugiyono. 2010. Metode Penelitian Pendidikan Pendekatan Kuantitatif dan Kualitatif. Bandung:Alfabeta.

Suherman, Erman dkk. 2003. Strategi Pembelajaran Matematika Kontemporer. Bandung: UPI

Susanto, Ahmad. 2012. Teori Belajar dan Pembelajaran. Jakarta: Kencana Prenadamedia Group.

Suryabrata. 2003. Metodologi Penelitian. Jakarta: PT Raja Grafindo Persada.

Syarif, Makmur. 2014. Pedoman Penulisan Karya Ilmiah (Tugas Akhir, Skripsi, Tesis dan Disertasi). Padang: IAIN Imam Bonjol Padang.

Trianto. 2007. Model-Model Pembelajaran Inovatif Berorientasi Konstruktivis. Jakarta : Prestasi Pustaka

Undang-undang RI No. 20 Tahun 2003. Sistem Pendidikan Nasional. Jakarta: Sinar Grafika. 